\title{
The role of the companion animal veterinary surgeon in behavioural husbandry Kendal Shepherd
}

Address: 16 Church Street, Finedon, Wellingborough, Northants, NN9 5NA, UK

Email: Kendal Shepherd - kendal@lindenarts.co.uk

from The role of the veterinarian in animal welfare. Animal welfare: too much or too little? The 2 Ist Symposium of the Nordic Committee for Veterinary Scientific Cooperation (NKVet)

Værløse, Denmark. 24-25 September 2007

Published: 19 August 2008

Acta Veterinaria Scandinavica 2008, 50(SuppI I):SI2 doi:I0.II86/I75I-0I47-50-SI-SI2

This abstract is available from: http://www.actavetscand.com/content/50/SI/SI2

(c) 2008 Shepherd; licensee BioMed Central Ltd.

An American Veterinary Medical Association mission statement regarding the human-animal bond reads, "The veterinary surgeon's role in the human-animal bond is to maximise the potential of this relationship between people and animals." To fulfil this aim and implicit obligations, as well as enhancing the welfare of both human and animal companion, it is impossible to ignore the emotional and behavioural aspects of this relationship in favour of purely physiological illness and disease. Rather than only addressing defects in the dog-human relationship which have already occurred - the client complains about destruction in the home, urinating indoors or being snappy towards the children for example - the onus is now on all veterinary surgeons to be rather more proactive in their approach. It must be appreciated that a relationship does not exist merely between a particular pet and members of their family, but also between that animal and all the humans it may happen to come into contact with elsewhere, including those inhabiting veterinary surgeries. The dog which becomes progressively harder to handle in the surgery over time, although frequently labelled as 'difficult', 'aggressive' or simply 'vicious', is in reality simply one whose behavioural needs and emotional welfare have been inadvertently damaged in the process of maintaining physical health or attending to physical disease. On the other hand, a dog who is genuinely pleased to enter a veterinary surgery, and whose behaviour and emotions have been nurtured in the same way as its physical needs, is a tribute to the attending veterinary surgeon as well as its owner.
At present, lack of adequate and appropriate behavioural management is routinely compromising much of the treatment vets try to deliver to their patients, both medical and surgical. In the UK, the new Animal Welfare Act (2007) stipulates that all those in contact with an animal have a 'duty of care' towards it, which encompasses both physical and mental needs, health and well being. It is therefore a legal, if not also moral, obligation of veterinary surgeons in the UK to ensure that necessary, effective and humane behavioural management is in place, bearing in mind these requirements. It would however often seem that farm animals have the better deal in this regard. Management systems and environment are routinely considered to have a bearing on the cow, sheep or pig's physical health and the development of disease, and are therefore automatically included in the large animal veterinary surgeon's remit. Not so for the domestic dog, which may be skidding uncomfortably on a fashionable laminate floor, subjected to the impact of noise from a multitude of household gadgets, or contained and punished with electric shock, and yet its small animal veterinary surgeon be completely unaware of its plight. How can we truly say such animals are 'under our care' if this is the case?

This poster presentation will summarise some of the very simple means whereby not only appropriate behaviour, but also accompanying emotions, can be generated and maintained in dogs in all veterinary contexts. Using basic knowledge of learning theory and its practical application, the behavioural repertoire of a dog can be manipulated and cared for in such a way as to ensure emotional welfare 
and maximum success of medical and surgical veterinary interventions. Not only will such care have benefits within the context of the surgery, as a dog's need to become aggressive will be diminished, but veterinary surgeons and nurses will be presented as 'role models' to be emulated by their clients in all aspects of the animal's life. It will help prevent iatrogenic behavioural damage, allow 'best practice' in terms of clinical care, and result in much improved client loyalty and compliance. Above all, the field of behaviour must not be viewed as time-consuming and financially inefficient, only to be tackled on a 'caseby-case' basis. Instead, it must become second nature for any veterinary surgeon to consider both external behaviour and underlying emotions as part of his or her daily clinical repertoire and demonstrate routine care for them. This is the basis of 'behavioural husbandry'.

Publish with Bio Med Central and every scientist can read your work free of charge

"BioMed Central will be the most significant development for disseminating the results of biomedical research in our lifetime. " Sir Paul Nurse, Cancer Research UK

Your research papers will be:

- available free of charge to the entire biomedical community

- peer reviewed and published immediately upon acceptance

- cited in PubMed and archived on PubMed Central

- yours - you keep the copyright

Submit your manuscript here:

http://www.biomedcentral.com/info/publishing_adv.asp 